Practice Current: An interactive exchange on controversial topics Luca Bartolini, MD, Section Editor

\title{
How do you treat anti-NMDA receptor encephalitis?
}

Luca Bartolini, MD

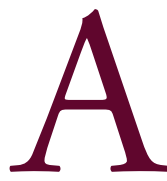

nti-NMDA receptor (anti-NMDAR) encephalitis was first described in $2007^{1}$ and is now recognized as one of the most common forms of encephalitis. ${ }^{2}$ AntiNMDAR encephalitis is considered a multistage disease, characterized by nonspecific prodromal flu-like symptoms, followed by acute onset of psychiatric manifestations such as psychosis, delusions, hallucinations, anxiety, insomnia, repetitive behaviors, echolalia, and mutism. Patients at this stage generally present to either neurology or psychiatry services. This phase is usually followed by a change in level of alertness with periods of extreme agitation and catatonia along with the appearance of the classic orofacial and lingual dyskinesias or other movement disorders and pronounced autonomic instability. The combination of autonomic storms and coma often

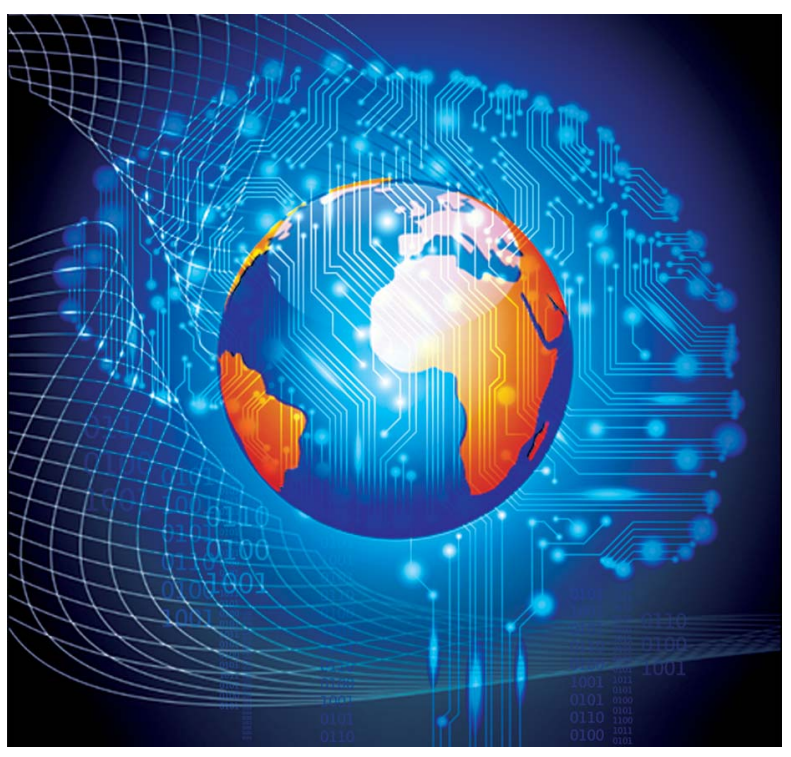
leads to a prolonged intensive care unit (ICU) admis-

sion. Patients — children in particular — can also develop focal or generalized seizures. AntiNMDAR encephalitis can be associated with a tumor, especially ovarian teratomas in female patients older than 12 years. Brain MRI is normal in up to 67\% of patients, whereas EEG is abnormal in $90 \%$ of patients. ${ }^{3}$ EEG findings are nonspecific and can include slowing, disorganization of the background, and electrographic seizures. The diagnosis is confirmed by the presence of NMDAR antibodies in the CSF.

\section{Current evidence on treatment}

Treatment protocols consist of supportive measures, immunotherapy, and tumor removal, when present. Generally, first-line immunotherapies for this condition consist of high-dose steroids, IV immunoglobulin (IVIg), and plasma exchange (PE). Different institutions have utilized these treatments alone, in combination, or sequentially; as of yet, no data have confirmed the superiority of one approach over the others. Rituximab and cyclophosphamide are usually considered second-line treatments, and reserved for those patients who fail the first line.

A large observational study that examined 577 patients reported the following 3 : 94\% of patients underwent first-line therapy or tumor removal and half of them improved significantly after 4 weeks. A total of $57 \%$ of the patients who did not improve received second-line 


\section{Now I believe we are moving more toward a} comprehensive immunotherapy that consists of giving rituximab, IVIg or PE, and methylprednisolone up front all at the same time.

agents. A total of $78 \%$ of treated patients achieved a modified Rankin Scale score $\leq 2$ by 24 months compared with only $55 \%$ of those who did not receive second-line therapy (odds ratio $2.69,95 \%$ confidence interval $1.24-5.80$ ). Overall, $81 \%$ of patients had a good outcome at 24 months and second-line immunotherapy also decreased the risk of relapses. Other factors associated with good outcome included tumor removal (when present), no need for admission to the ICU, and shorter interval between symptom onset and treatment. A total of 45 patients had one or multiple relapses (a 12\% risk within 2 years).

Other small series have analyzed the outcome of both pediatric and adult patients with antiNMDAR encephalitis and concluded that early therapy is important for improved clinical outcome. $^{4-6}$

To date, there has been no prospective open-label treatment trial to evaluate the efficacy of these treatments and all existing evidence is graded as Class IV (according to the American Academy of Neurology Classification of Evidence Matrices for therapeutic, causation, and prognostic questions). ${ }^{7}$

\section{Expert opinion: Josep Dalmau, MD, PhD}

At present, there is no standardized protocol. We have used combined IVIg $0.4 \mathrm{~g} / \mathrm{kg} / \mathrm{d}$ for 5 days and methylprednisolone $1 \mathrm{~g} / \mathrm{d}$ for 5 days as first-line treatment, with no steroid taper afterwards. There are no data to support that PE is superior to IVIg. From an immunological perspective, the antibodies are synthesized both systemically and inside the brain so PE can remove them systemically but cannot alter the autoimmune process that is going on inside the brain. This is why up to $14 \%$ of patients do not have serum antibodies but do have positive CSF. Also, it can be very challenging to do it in patients with autonomic instability and extreme agitation. The response to first-line treatment is usually evaluated clinically after 10-15 days (titers help with the diagnosis but not with the efficacy of treatment). More than half of the patients fail to respond and they will benefit from second-line immunotherapy, which usually consists of rituximab (that eliminates the B-cell lineage and therefore prevents the formation of plasma cells), given for example at a dose of $375 \mathrm{mg} / \mathrm{m}^{2}$ every week for 4 weeks and often times combined with monthly cycles of cyclophosphamide $750 \mathrm{mg} / \mathrm{m}^{2}$ for 4-6 months (an alkylating agent that interferes with DNA replication and eliminates $\mathrm{T}$ regulatory cells_-Ed.), especially in adults. Now I believe we are moving more toward a comprehensive immunotherapy that consists of giving rituximab, IVIg or $\mathrm{PE}$, and methylprednisolone up front all at the same time. In Hospital Clinic at the University of Barcelona, we include as part of this comprehensive immunotherapy rituximab and both PE and IVIg. In this protocol, $6 \mathrm{PE}$ are given over 10 days, with replacement of the protein losses with albumin, and followed by IVIg. At this time, it is unclear whether the combination of PE and IVIg is better than one of them alone, but I am of the opinion that early aggressive treatment is extremely important to alter the natural course of the disease, which can be lethal, and to prevent relapses. If a patient has a relapse, we usually consider repeating the same treatment that had helped initially or giving a second-line agent if it was not given previously. We currently do not use mycophenolate and azathioprine. In fact, there are no studies to show that these drugs are effective in the acute stage or are useful to prevent relapses. We definitely need multicenter prospective studies to evaluate the efficacy of all these immunotherapies. 


\section{Preliminary poll results (December 15, 2015; 9 AM EST)}

The preliminary results from the first 172 responders 2 weeks after the poll launched show that almost 50\% $(\mathrm{n}=80)$ utilize IVIg and high-dose steroids as first-line treatment. A small but growing number of readers $(n=16)$ seems to agree with Dr. Dalmau's approach and utilize the aforementioned comprehensive immunotherapy. The majority $(n=11)$ in this subgroup resides outside of the United States. It will be interesting to see if there is indeed a different comfort zone in regard to immunotherapy in other countries or if these numbers will change over time with more responses. So far, there is no surprise in terms of second-line treatment, which is usually considered $1(38 \%)$ or 2 weeks $(39 \%)$ after first-line treatment and is dominated by rituximab alone $(61 \%)$, even with $80 \%$ of responders in this subgroup whose practice is adult-based.

Thirty percent $(n=48)$ of those who have participated thus far are residents or fellows. It is encouraging to see how trainees are supporting this new editorial journey. Their opinion is invaluable, and sometimes may reflect in a single answer what an entire university-based group does on average.

\section{CONCLUSION}

It is clear that there is no single right answer to the question "How do you treat anti-NMDA receptor encephalitis?" Decisions are currently based on level IV evidence. Knowing that several patients with anti-NMDAR encephalitis improve after first-line treatment, with an overall low rate of relapse, and knowing that all the immunotherapeutic options have side effects, would you treat those patients using the proposed comprehensive immunotherapy approach or would you rather use a stepwise approach? The debate is still open.

We look forward to this ongoing participation from neurology enthusiasts at all levels of training and to generating more discussions and studies based on a genuine Socratic principle: "I know that I know nothing."

Josep Dalmau, MD, PhD, is currently Research

Professor at the Catalan Institution for Research and Advanced Studies (ICREA) in IDIBAPS/Hospital Clinic, Associate Professor at the University of Barcelona, Adjunct Professor of Neurology at the University of Pennsylvania, and Guest Researcher at the National Institute of Health $(\mathrm{NIH})$. Dr. Dalmau's research is focused on autoimmune and paraneoplastic neurologic disorders. His recent work has revealed a new category of disorders mediated by antibodies to neuronal cell surface and CNS synaptic proteins. Dr. Dalmau is editor of Neurology: Neuroimmunology \& Neuroinflammation, associate editor of Neurology, and serves on the editorial board of the Journal of Neurology. He has served or chaired many scientific committees, including the Basic Science and Neuro-oncology Subcommittees of the American Academy of Neurology and the Annual Special Interest Group in Autoimmune Neurology at the annual meeting of the American Neurological Association. His research is funded by the $\mathrm{NIH}$ and the Spanish Health Institute. Dr. Dalmau has contributed to numerous textbooks and has published in leading journals including the New England Journal of Medicine, Journal of Clinical Oncology, Neurology, Lancet Neurology, Brain Pathology, Annals of Neurology, Brain, and Cell.

\section{REFERENCES}

1. Dalmau J, Tuzun E, Wu HY, et al. Paraneoplastic anti-N-methyl-D-aspartate receptor encephalitis associated with ovarian teratoma. Ann Neurol 2007;61:25-36.

2. Gable MS, Sheriff H, Dalmau J, Tilley DH, Glaser CA. The frequency of autoimmune N-methyl-Daspartate receptor encephalitis surpasses that of individual viral etiologies in young individuals enrolled in the California Encephalitis Project. Clin Infect Dis 2012;54:899-904. 
3. Titulaer MJ, McCracken L, Gabilondo I, et al. Treatment and prognostic factors for long-term outcome in patients with anti-NMDA receptor encephalitis: an observational cohort study. Lancet Neurol 2013;12:157-165.

4. Irani SR, Bera K, Waters $\mathrm{P}$, et al. N-methyl-D-aspartate antibody encephalitis: temporal progression of clinical and paraclinical observations in a predominantly non-paraneoplastic disorder of both sexes. Brain 2010;133:1655-1667.

5. Viaccoz A, Desestret V, Ducray F, et al. Clinical specificities of adult male patients with NMDA receptor antibodies encephalitis. Neurology 2014;82:556-563.

6. Byrne S, McCoy B, Lynch B, Webb D, King MD. Does early treatment improve outcomes in N-methyl-D-aspartate receptor encephalitis? Dev Med Child Neurol 2014;56:794-796.

7. Gronseth GS, Woodroffe LM, Getchius TS. Clinical Practice Guideline Process Manual. St. Paul, MN: American Academy of Neurology; 2011.

8. Gresa-Arribas N, Titulaer MJ, Torrents A, et al. Antibody titres at diagnosis and during follow-up of anti-NMDA receptor encephalitis: a retrospective study. Lancet Neurol 2014;13:167-177.

\section{AUTHOR CONTRIBUTIONS}

Dr. Luca Bartolini designed and drafted the article and interviewed the expert.

\section{STUDY FUNDING}

No targeted funding reported.

\section{DISCLOSURES}

L. Bartolini serves as the Practice Current Section Editor for Neurology: Clinical Practice.

\section{Related articles from AAN physician and patient resources}

\section{Neurology ${ }^{\circledR}$ Clinical Practice}

Paraneoplastic syndromes and autoimmune encephalitis: Five new things September 2012;2:215-223.

Diagnosis and treatment of rapidly progressive dementias

September 2012;2:187-200.

\section{Neurology ${ }^{\circledR} \quad$ - Neurology.org}

Seizures as first symptom of anti-NMDA receptor encephalitis are more common in men February 18, 2014;82:550-551.

Late-onset anti-NMDA receptor encephalitis

September 17, 2013;81:1058-1063.

\section{Continuum ${ }^{\circledR}$ • ContinuumJournal.com}

Paraneoplastic Disorders

April 2015;21:452-475.

Paraneoplastic Neuropathies

October 2014;20:1359-1372.

\section{Neurology Today ${ }^{\circledR} \quad$ - Neurotodayonline.com}

Brain Antigen-Directed Autoantibodies Found Comparably Detectable in Healthy and Diseased Groups

October 2, 2014;14:13-17. 


\title{
Neurology ${ }^{\circ}$ Clinical Practice
}

\author{
Practice Current: How do you treat anti-NMDA receptor encephalitis? \\ Luca Bartolini \\ Neurol Clin Pract 2016;6;69-72 Published Online before print January 29, 2016 \\ DOI 10.1212/CPJ.0000000000000219
}

\section{This information is current as of January 29, 2016}

\begin{tabular}{|c|c|}
\hline $\begin{array}{l}\text { Updated Information \& } \\
\text { Services }\end{array}$ & $\begin{array}{l}\text { including high resolution figures, can be found at: } \\
\text { http://cp.neurology.org/content/6/1/69.full.html }\end{array}$ \\
\hline Supplementary Material & $\begin{array}{l}\text { Supplementary material can be found at: } \\
\text { http://cp.neurology.org/content/suppl/2016/03/29/CPJ.0000000000000 } \\
\text { 219.DC1 }\end{array}$ \\
\hline References & $\begin{array}{l}\text { This article cites } 7 \text { articles, } 0 \text { of which you can access for free at: } \\
\text { http://cp.neurology.org/content/6/1/69.full.html\#\#ref-list-1 }\end{array}$ \\
\hline Citations & $\begin{array}{l}\text { This article has been cited by } 2 \text { HighWire-hosted articles: } \\
\text { http://cp.neurology.org/content/6/1/69.full.html\#\#otherarticles }\end{array}$ \\
\hline Subspecialty Collections & $\begin{array}{l}\text { This article, along with others on similar topics, appears in the } \\
\text { following collection(s): } \\
\text { All Immunology } \\
\text { http://cp.neurology.org//cgi/collection/all_immunology } \\
\text { Encephalitis } \\
\text { http://cp.neurology.org//cgi/collection/encephalitis } \\
\text { Practice Current } \\
\text { http://cp.neurology.org//cgi/collection/practice_current }\end{array}$ \\
\hline Permissions \& Licensing & $\begin{array}{l}\text { Information about reproducing this article in parts (figures,tables) or in } \\
\text { its entirety can be found online at: } \\
\text { http://cp.neurology.org/misc/about.xhtml\#permissions }\end{array}$ \\
\hline Reprints & $\begin{array}{l}\text { Information about ordering reprints can be found online: } \\
\text { http://cp.neurology.org/misc/addir.xhtml\#reprintsus }\end{array}$ \\
\hline
\end{tabular}

Updated Information \&

Supplementary Material

References

\section{Citations}

Subspecialty Collections

Neurol Clin Pract is an official journal of the American Academy of Neurology. Published continuously since 2011, it is now a bimonthly with 6 issues per year. Copyright ( 92016 American Academy of Neurology. All rights reserved. Print ISSN: 2163-0402. Online ISSN: 2163-0933.

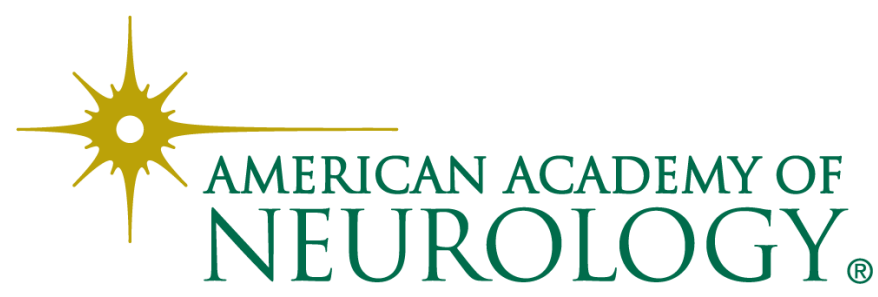

